\title{
AKTIVASI PERAN BINA KELUARGA REMAJA DALAM \\ PENGURANGAN RESIKO BENCANA BANJIR MENUJU \\ KEMANDIRIAN BENCANA DIKAMPUNG \\ KB PUCANGSAWIT, SURAKARTA
}

\author{
Dewi Kartika Sari ${ }^{1)}$ Rina Sri Widayati ${ }^{2}$ Yulaikha Istiqomah ${ }^{3)}$ Saftirta Gatra Dewantara \\ ${ }^{4)}$ Sandy Anwar Mursito ${ }^{5)}$ Jani Kusanti ${ }^{\text {9) }}$ \\ 1,2 Fakultas Ilmu Kesehatan, Universitas Aisyiyah Surakarta \\ 3.4.5 Mahasiswa Universitas Aisyiyah Surakarta \\ ${ }^{6}$ Universitas Surakarta \\ E-mail: rinasriwidayati_rinasriwidayati@gmail.com
}

\begin{abstract}
Flood is a natural event caused by the overflowing of water out of the river channel because the volume of water exceeds the capacity of the available river channels. An area of overflow from a river is referred to as a flood-plain area. Kampung KB which is located in Pucang sawit Village, Jebres, Surakarta, is located along the side of the Bengawan Solo river, making this location prone to the impact of the overflowing of the Bengawan Solo river in this extreme weather. Therefore, disaster mitigation activities in the form of flood disaster management are needed for the people of that area. The prevalence of heavy rain in Indonesia is increasing, resulting in an increased risk of flooding. The result of this problem is the lack of public knowledge regarding how to deal with flood disasters that may arise. The solution is with disaster training in the form of activating the role of youth family development in the KB village. The target output expected from this health education is the increasing number of people who know the procedures for handling floods in disaster locations, as well as youth being able to play an active role in disaster activities. Information on the Activation of Action and the Role of Youth in Flood Disaster Management in Kampung KB Pucangsawit, Surakarta was held on the 21st October 2020, followed by five students, two accompanying lecturers and audiences. During the counseling, a demonstration of first aid was carried out in the case of floods and questions and answers to clarify the understanding of the residents. After counseling about first aid to flood victims, we also did scene designs or actions in the field and practiced what had been taught directly on the banks of the Bengawan Solo river.
\end{abstract}

Keywords: Activation; Role; Youth Family; Disaster 


\section{PENDAHULUAN}

Banjir adalah peristiwa meluapnya air sungai melebihi palung sungai. (PasalAyat 7 Peraturan Pemerintah Republik Indonesia Nomor 38 Tahun 2011 Tentang Sungai). Dataran banjir adalah dataran di sepanjang kiri dan atau kanan sungai yang tergenang air pada saat banjir. (Pasal Ayat 3 Peraturan Pemerintah Republik Indonesia Nomor 38 Tahun 2011 Tentang Sungai).

Banjir merupakan suatu peristiwa alamiah yang disebabkan oleh meluapnya air keluar alur sungai karena volume air yang melebihi kapasitas saluran sungai yang tersedia. Wilayah luapan air sungai disebut sebagai daerah daratan banjir (flood-plain area).

Badan Meteorologi, Klimatologi, dan Geofisika (BMKG) menyampaikan bahwa sedang terjadi fenomena La Nina di Samudera Pasifik dengan intensitas sedang. BMKG mengatakan fenomena La Nina berpotensi meningkatkan curah hujan di sebagian wilayah Indonesia, sehingga risiko terjadinya banjir dan juga tanah longsor menjadi lebih besar. Ada dua jenis banjir yakni banjir daerah hulu dan banjir daerah hilir, yang pencegahan dan penanggulangannya tentu berbeda. Selama ini pedoman dasar yang dipergunakan untuk pengelolaan air, yaitu air hujan yang jatuh ke permukaan tanah yang penting dapat dialirkan menuju saluran, parit, sungai kecil, sungai besar dan seterusnya akhirnya ke laut. Pedoman ini harus diganti dengan mengusahakan agar air hujan sebanyak mungkin diresapkan ke dalam tanah dan sedikit mungkin mengalir di permukaan tanah.

Penyebab banjir untuk wilayah hilir atau daerah pantai, pengaruh laut terutama pasangsurut laut dan ketinggian elevasi daratan sangat mempengaruhi. Meskipun air kiriman melalui sungai besar tertentu dari wilayah hulu tetap sebagai pemicu banjir, namun tanpa air kiriman itu wilayah hilir pun dapat juga mengalami banjir karena hujan lokal yang intensif dengan iystem drainase yang buruk serta air yang berasal dari pasang laut. Kasus banjir rob di wilayah pantai utara Jakarta merupakan contoh dari kasus ini. Sedangkan untuk mengendalikan banjir yang terjadi tipe wilayah hilir atau daerah pantai ketika terjadi banjir adalah membangun tanggul-tanggul penahan ombak untuk penahan air pasang atau banjir rob, dan membangun sistem pemompaan air untuk memompa air laut ke laut secara efektif

Kampung KB yang terletak di Desa Pucang sawit, Jebres, Surakarta, berlokasi di sepanjang sisir sungai Bengawan Solo menjadikan lokasi tersebut rawan terkena dampak meluapnya sungai Bengawan Solo dalam cuaca ekstrem seperti ini. Oleh 
karena itu, kegiatan mitigasi bencana berupa penanganan bencana banjir diperlukan bagi masyarakat daerah tersebut. Prevalensi terjadinya hujan deras di Indonesia semakin meningkat, mengakibatkan resiko terjadinya bencana banjir juga meningkat. Akibat yang dapat ditimbulkan dari permasalahan tersebut yaitu kurangnya pengetahuan masyarakat terkait dengan cara menangani bencana banjir yang mungkin timbul.

\section{MASALAH, TARGET DAN LUARAN}

Prevalensi terjadinya hujan deras di Indonesia semakin meningkat, mengakibatkan resiko terjadinya bencana banjir juga meningkat. Akibat yang dapat ditimbulkan dari permasalahan tersebut yaitu kurangnya pengetahuan masyarakat terkait dengan cara menangani bencana banjir yang mungkin timbul. Menambah wawasan masyarakat terkait dengan manajemen banjirMasyarakat mengetahui cara menangani bencana banjir Masyarakat mampu megetahui dasardasar pertolongan pertama dalam bencana, khususnya bencana banjir. Target luaran yang diharapkan dari penyuluhan kesehatan ini yaitu, bertambahnya masyarakat yang mengetahui prosedur penanganan banjir dalam lokasi bencana, serta remaja mampu berperan aktif dalam kegiatan kebencanaan

\section{METODE PELAKSANAAN}

1. Tahap Perencanaan

Pelaksanaan program pengabdian masyarakat "pertolongan pertama korban bencana banjir" yang dilaksanakan di Kampung $\mathrm{Kb}$ melalui metode presentasi dan diskusi serta demonstrasi dan pelatihan. Tahap perencanaan dilakukan dengan cara pembentukan dan pembekalan tim PKM-M yang terdiri atas 5 mahasiswa yang selanjutnya menyusun proposal dan kemudian diajukan. Program ini dilaksanakan pada tanggal 21 Oktober 2020.

2. Tahap Persiapan

Tahap persiapan dilakukan dengan memulai berkoordinasi dengan pengurus Kampung Kb. Pada tahap persiapan ini tim pengabdian mengontrak waktu dengan pengurus serta menjelaskan kepada pengurus mengenai bentuk kegiatan yang akan dilakukan yaitu memberikan penyuluhan mengenai pertolongan pertama pada korban banjir. Selanjutnya tim pengabdian juga menjelaskan apa saja kegiatan yang akan dilakukan, struktur dan tugas dari tim pengabdian dan tugas masyarakat. Setelah dicapai kesepakatan, masih pada tahap persiapan, tim pengabdian bersama pengurus 
Kampung Kb beserta perangkatnya akan mengindentifikasi kelompok masyarakat yang diikut sertakan dalam kegiatan penyuluhan ini.

\section{Tahap Pelaksanaan}

Sebelum penyuluhan dimulai peserta melakukan pengecekan suhu tubuh, mencuci tangan, peserta dikumpulkan dalam satu ruangan dan melakukan social distancing. Metode presentasi dan diskusi akan dipandu oleh Tim pelaksana Kegiatan PKM-M. Dengan menggunakan tahapan sosialisasi dan introduksi, mencakup tentang pengenalan Pertolongan pertama pada korban henti jantung dan pertolongan korban bencana banjir. .Adapun yang akan dibahas dalam presentasi ini yaitu menjelaskan mengenai korban henti jantung dan pertolongan korban banjir, serta mendemonstrasikan secara langsung cara pertolongan pertamanya. Sehingga diharapkan warga Kampung KB tersebut dapat menerapkan pada kejadian di sekitarnya apabila terjadi bencana banjir.

\section{HASIL PEMBAHASAN}

Waktu Kampung KB Desa Pucang Sawit Rabu, 21 Oktober 2020 jam 08.00Selesai. Setelah diberikan penjelasan dan melkukan demostrasi mengenai pertolongan pertama pada korban banjir, diharapkan warga kampung $\mathrm{KB}$ dapat mengetahui pertolongan pertama untuk korban banjir. Setelah mengikuti penyuluhan mengenai pertolongan pertama pada korban bencana banjir diharapkan warga kampung KB mampu: Tingkat pengetahuan warga tentang pertolongan pertama pada bencana banjir meningkat. Warga dapat melakukan atau menerapkan pertolongan pertama yang sudah diajarkan apabila terjadi bencana banjir. Warga dapat mengetahui mana korban yang harus segera diberi pertolongan (diutamakan)

Pelaksanaan Kegiatan

Pembukaan, Acara Inti, Perkenalan dan penyampaian tujuan dari penyuluhan “Aktivasi Aksi dan Peran Remaja dalam Penanganan Bencana Banjir di Kampung KB Pucangsawit", Penyampaian materi mengenai bencana banjir, Mewawancarai warga untuk mengkaji seberapa jauh warga mengetahui tentang bencana banjir, Mendemostrasikan cara memberikan pertolongan pertama dengan menggunakan media (phantom, mitella, tandu, spalek, dll), Meminta perwakilan warga untuk mencoba melakukan seperti yang di demostrasikan

Sharing yang berupa tanya jawab antara pemateri dengan warga. 


\section{Dokumentasi bersama}

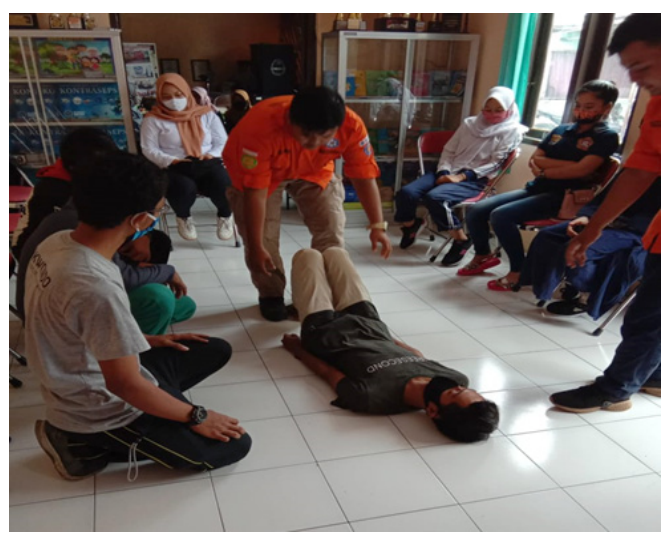

Setelah diberikan penyuluhan, sasaran penyuluhan mampu:Menjelaskan apa itu bencana banjir. Mengetahui bagaimana cara mencegah banjir. Mengetahui bagaimana memberikan pertolongan pertama pada korban bencana banjir. Mengetahui apa yang hasur dilakukan saat terjadi bencana banjir

Pada saat diberi penyuluhan "Aktivasi Aksi dan Peran Remaja dalam Penanganan Bencana Banjir di Kampung KB Pucangsawit", warga terlihat aktif dalam mengikuti penyuluhan. Dengan adanya demonstrasi pemberian pertolongan pertama pada korban bencana banjir dapat memperjelas materi yang disampaikan oleh pemateri. Dan dengan adanya warga yang mencoba mempraktekkan apa yang sudah didemonstrasikan, dapat memperjelas tingkat pemahaman warga terhadap materi yang sudah disampaikan. Manajemen risiko merupakan kegiatan mendasar yang diarahkan untuk mengevaluasi skema untuk mengurangi risiko tetapi tidak untuk menghilangkan semua risiko, karena risiko dalam banyak kasus tidak dapat sepenuhnya dihilangkan. "masalah air" juga merupakan "masalah orang". Manajemen Risiko Banjir karena itu memerlukan pendekatan holistik, ilmiah untuk menangani isu-isu rekayasa curah hujan, air hujan, sungai, genangan banjir dan isu-isu sosial ekonomi mengenai perencanaan, pengembangan dan manajemen. Ada tiga komponen penting dalam manajemen risiko banjir yaitu menentukan risiko dari bahaya, vulnerability dan eksposur dari banjir. Namun, risiko banjir telah didefinisikan dalam beberapa cara dalam literatur bahaya alam, namun salah satu nya adalah dalam kerangka definisi berikut ini:

Bahaya, peristiwa alam yang mengancam termasuk probabilitas/besar kejadian

Exposure, nilai-nilai/manusia yang terlibat dan berapa pada lokasi.

Vulnerability, kurangnya (atau longgar) perlawanan untuk perusak/kekuatan destruktif.

Komponen bahaya dan vulnerability akan saling berkolaborasi untuk menghasilkan bencana. Risiko Banjir secara matematis dapat dihitung sebagai produk dari bahaya, eksposur dan vulnerability. Dengan mengikuti pendekatan ini database GIS dapat dirancang dan dikembangkan untuk mewakili spasial ketiga komponen risiko tersebut. 
Manajemen risiko banjir bertujuan untuk mengurangi kemungkinan dan/atau dampak banjir. Pengalaman menunjukkan bahwa pendekatan yang paling efektif adalah melalui pengembangan program-program manajemen risiko banjir dengan menggabungkan unsurunsur berikut:

1. Pencegahan, mencegah kerusakan yang disebabkan oleh banjir dengan menghindari pembangunan rumah-rumah dan industri di masa kini dan masa depan daerah yang rawan banjir. Dengan menyesuaikan perkembangan masa depan untuk resiko banjir, dan dengan mempromosikan penggunaan lahan yang tepat untuk praktek-praktek pertanian dan kehutanan.

2. Perlindungan, mengambil langkahlangkah, baik struktural dan nonstruktural, untuk mengurangi kemungkinan banjir dan/atau dampak banjir di lokasi tertentu.

3. Persiapan, memberitahu penduduk tentang risiko banjir dan apa yang harus dilakukan jika terjadi banjir;

4. Respon darurat, mengembangkan rencana respon darurat dalam kasus banjir;

Pemulihan dan pelajaran yang dipetik, kembali ke kondisi normal sesegera mungkin dan mitigasi baik dampak sosial dan ekonomi pada penduduk yang terkena bencana.
Sebuah perubahan proaktif untuk manajemen risiko bencana alam memerlukan identifikasi risiko, pengembangan strategi untuk mengurangi risiko tersebut serta penciptaan kebijakan dan program untuk menjalankan strategi ini. Salah satu kunci output dari rencana manajemen risiko banjir adalah membuat peta-peta risiko banjir di tingkat daerah aliran sungai. Tujuan dari peta risiko banjir adalah untuk: Meningkatkan kesadaran masyarakat dari kawasan yang beresiko banjir. Memberikan informasi tentang daerah beresiko dengan menentukan zona resiko banjir untuk memberikan masukan bagi perencanaan tata ruang. Mendukung proses memprioritaskan, membenarkan dan menargetkan investasi dalam rangka untuk mengelola dan mengurangi risiko pada orang, properti dan lingkungan Penilaian risiko banjir merupakan masalah kompleks yang hanya dapat dipecahkan melalui penelitian lintas disiplin. Sebuah pendekatan dengan dua langkah telah diadopsi, yaitu: Pertama, diperlukan pendeteksian bahaya banjir menggunakan seperangkat indikator yang dipilih, seperti distribusi spasial kecepatan aliran, ketinggian air, kecepatan propagasi, durasi, dll. Kedua, adalah untuk memperkirakan bagaimana indikator bahaya banjir yang mengganggu kegiatan manusia di daerah banjir. Kegiatan pertanian akan menderita kerusakan dengan cara yang 
berbeda daripada misalnya zona industri atau wilayah perkotaan. Aspek perlindungan sipil juga harus dipertimbangkan, seperti ketika orang harus dievakuasi dan jalur transportasi yang masih tersedia di wilayah banjir.

\section{KESIMPULAN DAN SARAN}

Kegiatan penyuluhan Aktivasi Aksi dan Peran Remaja dalam Penanganan Bencana Banjir di Kampung KB Pucangsawit, Surakarta dilaksanakan pada tanggal 21 Oktober 2020, dengan diikuti lima orang mahasiswa, dua orang dosen pendamping dan audiens. Dalam penyuluhan dilakukan demonstrasi pertolongan pertama pada bencana banjir dan tanya jawab guna memperjelas pemahaman warga. Setelah dilakukan penyuluhan mengenai pertolongan pertama pada korban bencana banjir kami juga melakukan reka adegan atau aksi dilapangan dan mempraktikkan yang sudah di ajarkan secara langsung di pinggiran sungai bengawan solo. Sesuai hasil evaluasi respon audiens yang telang dilakukan, kami menyarankan hendaknya program-program pengabdian masyarakat seperti ini dilaksanakan lebih sering guna menambah

Tingkat pengetahuan masyarakat tentang kesehatan dan kebencanaan.Ucapan Terima kasih atas hibah PPDM KEMENRISTEKTEK BRIN tahun 2020 .

\section{DAFTAR PUSTAKA}

Wolfgang, Bollin. Christina, "Disaster Risk Management Working Concept",

Deutsche Gesellschaft für Technische Zusammenarbeit (GTZ) GmbH, 2002.

Karolak, Dare. Walter, "Software Engineering Risk Management”, IEEE Computer Society Press, 1996.

MacDonald. Mott, "Cambridge City Strategic Flood Risk Assessment, Final Report", Cambridge City Council, February 2006.

Stoneburner. Gary, Goguen. Alice, Feringa. Alexis, "Risk Management

Guide for Information Technology Systems”, NIST, 2002. 
Word Meteorological Organization (WMO), "Urban Flood Risk Management”, Asoociated Programme On Flood Management, March 2008.

Restu - Andi - Bella. 2017. KAJIAN ALTERNATIF PENANGGULANGAN BANJIR (Studi Kasus DAS Ciujung Bagian Hulu, Banten). Jurnal Konstruksia.Volume 8 Nomer 2. 